\title{
Effect of prepartum photoperiod and melatonin feeding on milk production and prolactin concentration in dairy heifers and cows
}

\author{
P. Lacasse, C. M. Vinet, ${ }^{1}$ and D. Petitclerc ${ }^{2}$ \\ Dairy and Swine Research and Development Centre, Agriculture and Agri-Food Canada, Sherbrooke, Quebec, Canada J1M 0C8
}

\begin{abstract}
Holstein multiparous cows $(\mathrm{n}=29)$ and primiparous heifers $(\mathrm{n}=32)$ calving over a 1 -yr period were subjected to photoperiod-melatonin treatments according to a $2 \times 3$ factorial design. Starting 8 wk before expected calving, all animals were subjected to 1 of the following treatments: $8 \mathrm{~h}$ of light and $16 \mathrm{~h}$ of dark (8L:16D), $16 \mathrm{~h}$ of light and $8 \mathrm{~h}$ of dark (16L:8D), or 16L:8D plus melatonin feeding (16L:8D-melatonin). Each day at $1355 \mathrm{~h}$, the animals in the melatonin treatment received orally a gelatin capsule containing $25 \mathrm{mg}$ of melatonin. The treatments ended at calving, when the animals were moved to the lactation barn; all animals were then subjected to about $16 \mathrm{~h}$ of light per day. At the beginning and end of the treatment period before calving, blood samples were taken from 6 heifers and 6 cows through a jugular cannula for $24 \mathrm{~h}$ at 30 -min intervals to monitor serum melatonin and prolactin concentrations. Milk production in the heifers was not affected by the photoperiod treatments. Early-lactation milk production was higher in the cows exposed to the short-day photoperiod than in those exposed to a long-day photoperiod (16L:8D and 16L:8D-melatonin), with averages of $36.7 \pm 0.9$, $33.1 \pm 0.8$, and $34.1 \pm 0.9 \mathrm{~kg} / \mathrm{d}$ for $8 \mathrm{~L}: 16 \mathrm{D}, 16 \mathrm{~L}: 8 \mathrm{D}$, and 16L:8D-melatonin, respectively. Photoperiod had no effect on late-lactation milk production in the cows. During lactation, the dry matter intake of heifers was not affected by the treatments, but dry matter intake of the cows exposed to a short-day photoperiod was greater than that of the cows exposed to a long-day photoperiod. Feed efficiency of heifers was improved by short-day photoperiod. During the treatment period, prolactin concentration was lower in the animals exposed to a short-day photoperiod than in those exposed to a long-day photoperiod, was lower with the 16L:8Dmelatonin treatment than with the $16 \mathrm{~L}: 8 \mathrm{D}$ treatment, and tended to be lower with the $8 \mathrm{~L}: 16 \mathrm{D}$ treatment than
\end{abstract}

\footnotetext{
Received October 16, 2013.

Accepted February 12, 2014.

${ }^{1}$ Deceased.

${ }^{2}$ Corresponding author: denis.petitclerc@agr.gc.ca
}

with the 16L:8D-melatonin treatment, with averages of $3.5 \pm 0.8,9.9 \pm 0.8$, and $6.0 \pm 0.8 \mathrm{ng} / \mathrm{mL}$ for $8 \mathrm{~L}: 16 \mathrm{D}$, 16L:8D, and 16L:8D-melatonin, respectively. In early lactation, prolactin concentration was lower in the heifers exposed to the 16L:8D photoperiod during the dry period than in those exposed to the $8 \mathrm{~L}: 16 \mathrm{D}$ photoperiod or fed melatonin. In conclusion, a short-day photoperiod during the dry period transiently increases milk production of cows and the feed efficiency of heifers in the following lactation. However, melatonin cannot be used to mimic a short-day photoperiod during the dry period.

Key words: gestation, mammary development, cattle

\section{INTRODUCTION}

Photoperiod, which is the relative duration of light and dark exposure within a day, is an important environmental cue used by animals to predict and prepare for the change of seasons. In lactating dairy cows, exposure to a long-day photoperiod of $16 \mathrm{~h}$ of light and $8 \mathrm{~h}$ of dark (16L:8D) is associated consistently with an increase in prolactin (PRL) concentration and milk production (Dahl and Petitclerc, 2003). In contrast, cows exposed to a long-day photoperiod during the dry period produced less milk in the following lactation than those exposed to a short-day photoperiod (Miller et al., 2000; Auchtung et al., 2005; Velasco et al., 2008), although only the first $16 \mathrm{wk}$ of lactation were reported in those studies. Those results suggest that a short-day photoperiod represents a valuable management strategy for dry cows.

Even though the effect of photoperiod at the end of gestation has been the subject of several experiments, studies in primiparous heifers are scarce. Newbold et al. (1991) reported no effect of photoperiod on mammary growth in dairy heifers during gestation. However, the present authors observed in a previous experiment that early-lactation milk production was stimulated in heifers exposed to a short-day photoperiod ( $8 \mathrm{~h}$ of light and $16 \mathrm{~h}$ of dark, 8L:16D) during the last $8 \mathrm{wk}$ of gestation (Petitclerc et al., 1990). This result needs to be confirmed and, as for multiparous cows, the effect needs to be determined over a complete lactation. 
Most effects of photoperiod are mediated by endocrine changes. The light stimulus inhibits the secretion of melatonin by the pineal gland such that melatonin is high at night and low during the day (Stanisiewski et al., 1988). In beef heifers, feeding melatonin in the middle of the light period of a $16 \mathrm{~L}: 8 \mathrm{D}$ photoperiod was found to alter growth and carcass composition in a manner similar to a short-day photoperiod (Zinn et al., 1988). Therefore, exogenous melatonin may represent an alternative to a short-day photoperiod when photoperiod of the dry-cow cannot be housed separately from the lactating cows. The objective of this study was to determine the effect of photoperiod and melatonin feeding during the last 2 mo of gestation on the milk production in the subsequent and complete lactation and on PRL concentration in dairy heifers and cows.

\section{MATERIALS AND METHODS}

\section{Animals and Experimental Design}

The experiment was conducted in accordance with the guidelines of the Canadian Council on Animal Care (Ottawa, ON, Canada). Holstein multiparous cows $(\mathrm{n}=29)$ and primiparous heifers $(\mathrm{n}=33)$ calving over a 1-yr period were housed at the Agriculture and Agri-Food Canada Dairy and Swine Research and Development Centre (Sherbrooke, QC, Canada). The animals were subjected to treatments according to a 2 $\times 3$ factorial design, where the main effects were parity and photoperiod-melatonin treatments. Starting $8 \mathrm{wk}$ before expected calving, all animals were subjected to 1 of the following treatments: 8L:16D $(\mathrm{n}=19), 16 \mathrm{~L}: 8 \mathrm{D}$ $(\mathrm{n}=22)$, or $16 \mathrm{~L}: 8 \mathrm{D}$ plus melatonin feeding $(16 \mathrm{~L}: 8 \mathrm{D}-$ melatonin; $\mathrm{n}=21$ ). Lights were on from 0600 to $1400 \mathrm{~h}$ for $8 \mathrm{~L}: 16 \mathrm{D}$ and from 0600 to $2200 \mathrm{~h}$ for $16 \mathrm{~L}: 8 \mathrm{D}$ and 16L:8D-melatonin treatments. Each day at $1355 \mathrm{~h}$, the animals in the melatonin treatment received orally a gelatin capsule containing $25 \mathrm{mg}$ of melatonin. This dose was chosen based on work in beef heifers (Zinn et al., 1988). The treatments ended at calving, when the animals were moved to the lactation barn; all animals were then subjected to about $16 \mathrm{~h}$ of light per day. Prior to calving, the animals were fed a dry-period diet containing (on a DM basis) 34\% grass silage, 30\% alfalfa silage, $35 \%$ high-moisture cob corn, and $1 \%$ mineral supplements. During lactation, the animals were fed ad libitum TMR containing (on a DM basis) $45 \%$ alfalfa silage, $20 \%$ high-moisture cob corn, $19.8 \%$ micronized soybeans, $11.6 \%$ rolled barley, $2 \%$ distillers grain, and $1.6 \%$ mineral supplements in early lactation; $40 \%$ alfalfa silage, $25 \%$ high-moisture cob corn, $2.4 \%$ micronized soybeans, $9.3 \%$ soybean meal, $21.2 \%$ rolled barley, and $2.1 \%$ mineral supplements in mid lactation; and $58 \%$ alfalfa silage, $37 \%$ high-moisture cob corn, $2.4 \%$ soybean meal, and $2.6 \%$ mineral supplements in late lactation. Feed intake was recorded daily throughout lactation. The BW of each animal was determined every other week throughout the experiment. The cows were milked twice daily, at 0600 and $1800 \mathrm{~h}$, and milk yield was recorded at each milking. Milk samples were collected weekly (morning and afternoon milkings). Milk protein and fat concentrations were determined at a commercial laboratory (Valacta Inc., Sainte-Anne-deBellevue, QC, Canada).

Caudal blood samples were taken every other week from $10 \mathrm{wk}$ before to $40 \mathrm{wk}$ after calving and on the day of calving using uncoated Vacutainer tubes (Becton, Dickinson and Co., Rutherford, NJ). In addition, EDTA-coated Vacutainer tubes were used to collect blood samples on the day of calving and in wk 2, 4, and 6 of lactation. Within the first 2 wk of the treatment period and 2 wk before the expected calving date, blood samples were taken from 2 heifers and 2 cows per treatment through a jugular cannula for $24 \mathrm{~h}$ at 30-min intervals to monitor serum melatonin and PRL concentrations. All the uncoated blood tubes were left for approximately $2 \mathrm{~h}$ at room temperature for clotting before centrifugation $\left(1,900 \times g\right.$ for $15 \mathrm{~min}$ at $\left.4^{\circ} \mathrm{C}\right)$. The tubes with EDTA were kept on ice until centrifugation $\left(2,000 \times g\right.$ for $10 \mathrm{~min}$ at $\left.4^{\circ} \mathrm{C}\right)$. Plasma and serum samples were then kept at $-20^{\circ} \mathrm{C}$ until analysis.

\section{Hormone Concentrations}

Serum PRL concentration was measured by RIA as described by Lapierre et al. (1990). Bovine PRL, rabbit antiserum specific for bovine PRL, and goat anti-rabbit gamma globulin were purchased from the National Hormone and Peptide Program (Harbor-UCLA Medical Center, Torrance, CA). Plasma IGF-I was analyzed by RIA as described by Abribat et al. (1990), and serum melatonin was analyzed by RIA as described by Burchard et al. (2004).

\section{Statistical Analysis}

Data were analyzed by ANOVA using PROC MIXED of the SAS software package (SAS Institute Inc., Cary, NC). Time was used as a repeated effect, and animal was used as the subject. Preplanned orthogonal contrasts were used to compare animals on short days (8L:16D) to animals on long days (16L:8D and 16L:8D-melatonin) and to compare animals on 16L:8D to animals on 16L:8D-melatonin. Other treatment comparisons were performed using the Tukey-Kramer adjustment. Differences were considered statistically significant at $P<0.05$. 


\section{RESULTS}

Time $\times$ parity and time $\times$ treatment interactions $(P$ $<0.001$ ) for milk production were detected; therefore, data for heifers were analyzed separately from those for cows. Milk production in heifers was not affected by the photoperiod treatments (Figure 1). In cows, a time $\times$ treatment interaction $(P=0.05)$ existed; therefore, data for the first $20 \mathrm{wk}$ of lactation were analyzed separately from those for the second 20 wk. In early lactation, milk production was higher $(P<0.01)$ in the cows exposed to a short-day photoperiod than in those exposed to a long-day photoperiod $(16 \mathrm{~L}: 8 \mathrm{D}$ and 16L:8D-melatonin), with averages of $36.7 \pm 0.9,33.1$ \pm 0.8 , and $34.1 \pm 0.9 \mathrm{~kg} / \mathrm{d}$ for $8 \mathrm{~L}: 16 \mathrm{D}, 16 \mathrm{~L}: 8 \mathrm{D}$, and 16L:8D-melatonin, respectively. Photoperiod had no effect on late-lactation milk production, with averages of $25.3 \pm 1.1,24.8 \pm 1.0$, and $23.2 \pm 1.1 \mathrm{~kg} / \mathrm{d}$ for $8 \mathrm{~L}: 16 \mathrm{D}$, 16L:8D, and 16L:8D-melatonin, respectively. Feeding melatonin had no effect on milk production during either period.

Parity did not affect milk composition $(P>0.1)$. Milk fat content tended to be lower in the cows and heifers subjected to a short-day photoperiod (Table 1). The treatments did not affect milk protein content.
As was also the case for milk production, a significant time $\times$ parity interaction $(P<0.001)$ existed for fat, protein, and ECM yields; therefore, these data were analyzed separately for heifers and for cows. In heifers, fat, protein, and ECM yields were not affected by day length (Table 1). However, the heifers exposed to a long day and fed melatonin produced less fat and tended to produce less ECM than did the heifers exposed to a long day only. In cows, fat yield was not affected by the treatments (Table 1). Because of significant time $\times$ treatment interactions $(P<0.05)$, protein and ECM yield data for the first $20 \mathrm{wk}$ of lactation were analyzed separately from those for the second $20 \mathrm{wk}$. In early lactation, protein and ECM yields were higher in the cows exposed to a short-day photoperiod $(P<$ 0.01 ) than in those exposed to a long-day photoperiod (Table 1).

A parity $\times$ treatment interaction $(P=0.03)$ for DMI during lactation was detected; therefore, data for heifers were analyzed separately from those for cows. The DMI of heifers was not affected by the treatments (Table 1). However, the DMI of the cows exposed to a short-day photoperiod was greater than that of the cows exposed to a long-day photoperiod. Time $\times$ parity interactions $(P<0.05)$ existed for feed efficiency;

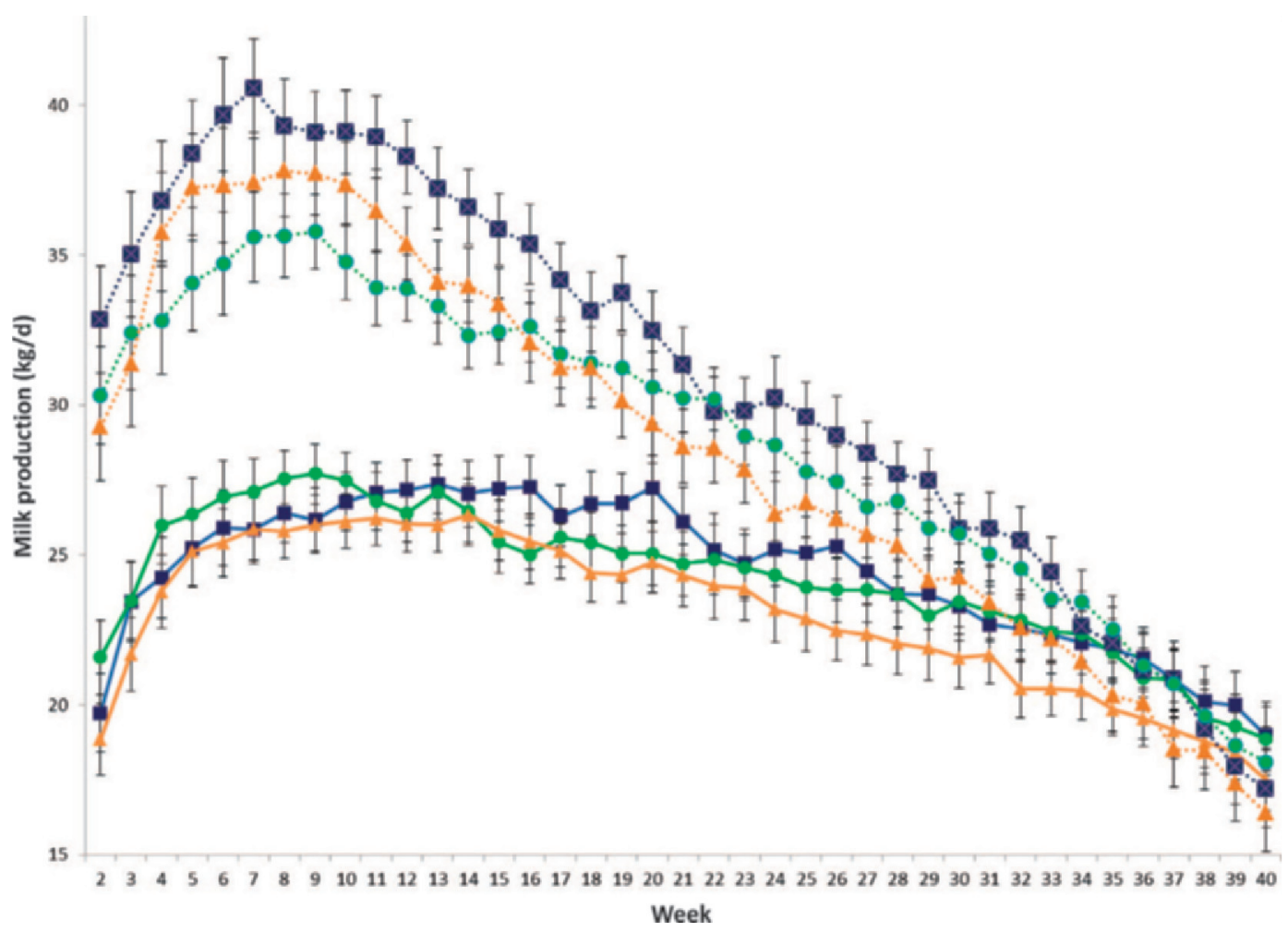

Figure 1. Milk production in heifers (solid lines) and cows (dotted lines) exposed to $8 \mathrm{~h}$ of light and $16 \mathrm{~h}$ of dark (8L:16D; $\mathbf{\square}), 16 \mathrm{~h}$ of light and $8 \mathrm{~h}$ of dark $(16 \mathrm{~L}: 8 \mathrm{D} ; \bullet)$, or 16L:8D with melatonin fed at $25 \mathrm{mg} / \mathrm{d}(\mathbf{\Delta})$ during the last 8 wk of gestation. Data are presented as LSM \pm SE of LSM. Color version available in the online PDF. 
Table 1. Effect of prepartum photoperiod and melatonin feeding on milk composition, ECM, DMI, and feed efficiency in dairy heifers and cows

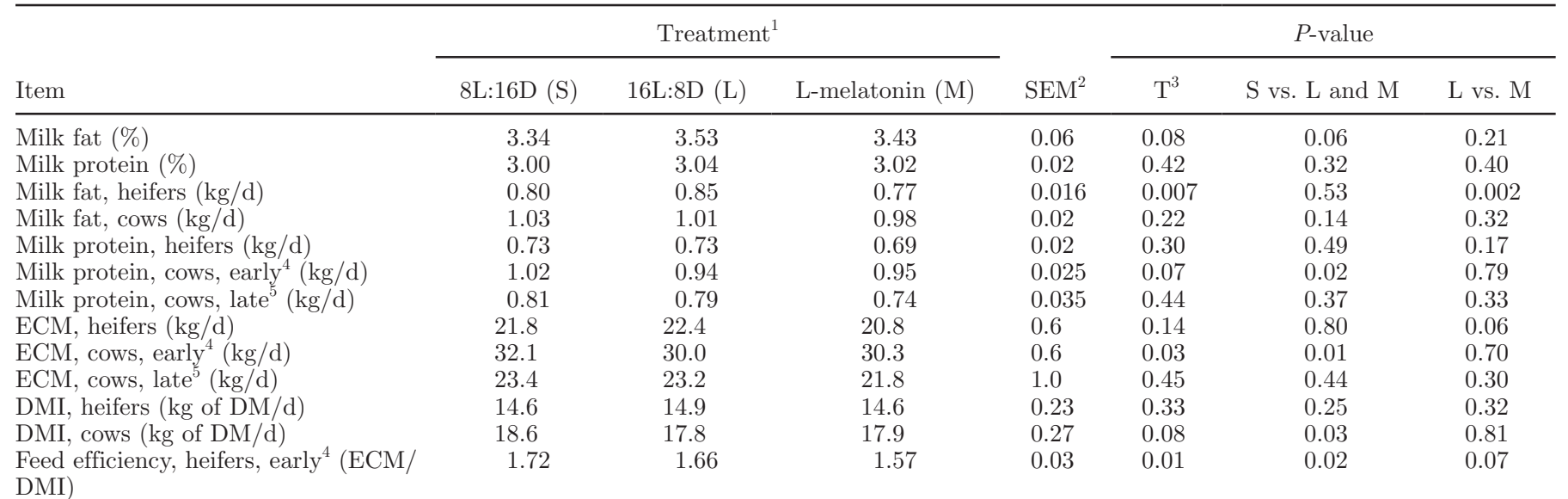

${ }^{1} 8 \mathrm{~L}: 16 \mathrm{D}=8 \mathrm{~h}$ of light and $16 \mathrm{~h}$ of dark per day; $16 \mathrm{~L}: 8 \mathrm{D}=16 \mathrm{~h}$ of light and $8 \mathrm{~h}$ of dark per day; L-melatonin $=16 \mathrm{~L}: 8 \mathrm{D}$ plus melatonin at $25 \mathrm{mg} / \mathrm{d}$.

${ }^{2}$ Standard error of the LSM.

${ }^{3} \mathrm{~T}=$ treatment.

${ }^{4}$ Weeks 2 to 20 of lactation.

${ }^{5}$ Weeks 21 to 40 of lactation.

therefore, data for heifers were analyzed separately from those for cows. Feed efficiency was not affected by photoperiod in cows (data not shown). In early lactation, feed efficiency was greater in the heifers exposed to a short-day photoperiod $(P<0.05)$ than in those exposed to a long-day photoperiod (Table 1). No effect of photoperiod on heifer feed efficiency was detected in the second half of lactation (data not shown). Body weight was not affected by the treatments $(P>0.25)$ during the treatment period and lactation (data not shown). None of the reproduction parameters evaluated (days at first estrus, number of services per conception, and days open) was affected by the treatments (data not shown).

During the first 2 wk of the treatment period and 2 wk before calving, blood samples were taken from 6 cows and 6 heifers every $30 \mathrm{~min}$ for $24 \mathrm{~h}$. For PRL concentration, a treatment $\times$ sampling day interaction $(P<0.05)$ was detected. For the first sampling day (Figure 2A), parity did not affect PRL concentration. The PRL concentration in the $16 \mathrm{~L}: 8 \mathrm{D}$ group was higher $(P<0.05)$ than the concentrations in the $8 \mathrm{~L}: 16 \mathrm{D}$ and the $16 \mathrm{~L}: 8 \mathrm{D}-$ melatonin groups, with averages of $5.7 \pm 1.6,11.5 \pm 1.6$, and $5.6 \pm 1.6 \mathrm{ng} / \mathrm{mL}$ for 8L:16D, 16L:8D, and 16L:8D-melatonin, respectively. For the second sampling day (Figure 2B), the PRL concentration in the 16L:8D group was higher $(P<$ $0.01)$ than the concentrations in the $8 \mathrm{~L}: 16 \mathrm{D}$ and the 16L:8D-melatonin groups, with averages of $6.8 \pm 1.1$, $15.9 \pm 1.1$, and $9.8 \pm 1.1 \mathrm{ng} / \mathrm{mL}$ for $8 \mathrm{~L}: 16 \mathrm{D}, 16 \mathrm{~L}: 8 \mathrm{D}$, and 16L:8D-melatonin, respectively. The concentration of PRL was greater in heifers $(13.2 \pm 0.9 \mathrm{ng} / \mathrm{mL})$ than in cows $(8.5 \pm 0.9 \mathrm{ng} / \mathrm{mL} ; P<0.01)$. For both sampling days, the effect of the treatments remained the same whether or not the lights were on at the time of sampling $(P>0.25)$. Melatonin concentration was not affected by parity or sampling day; however, a strong time of day $\times$ treatment interaction $(P<0.001)$ existed and, therefore, data were analyzed according to the lighting pattern. From 1430 to 2200 h (lights on for 16L:8D and off for 8L:16D), melatonin concentration was different for each treatment $(P<0.01$; Figure 3$)$, with averages of $35.1 \pm 5.1,12.1 \pm 5.1$, and $71.8 \pm$ $5.1 \mathrm{pg} / \mathrm{mL}$ for 8L:16D, 16L:8D, and 16L:8D-melatonin, respectively. From 2230 to 0600 h (lights off for all), melatonin concentration was greater in the animals fed melatonin than in those in the other treatments $(P<0.01)$ but was similar for $8 \mathrm{~L}: 16 \mathrm{D}$ and $16 \mathrm{~L}: 8 \mathrm{D}$, with averages of $30.1 \pm 3.5,32.2 \pm 3.5$, and $52.2 \pm$ $3.5 \mathrm{pg} / \mathrm{mL}$ for $8 \mathrm{~L}: 16 \mathrm{D}, 16 \mathrm{~L}: 8 \mathrm{D}$, and $16 \mathrm{~L}: 8 \mathrm{D}-m e l a t o n i n$, respectively. From 0630 to $1400 \mathrm{~h}$ (lights on for all), melatonin concentration was similar for all treatments, with averages of $16.7 \pm 3.1,15.2 \pm 3.1$, and $21.4 \pm$ $3.1 \mathrm{pg} / \mathrm{mL}$ for $8 \mathrm{~L}: 16 \mathrm{D}, 16 \mathrm{~L}: 8 \mathrm{D}$, and 16L:8D-melatonin, respectively.

The concentrations of PRL in the blood samples taken every other week from $10 \mathrm{wk}$ before to $40 \mathrm{wk}$ after calving are presented in Figure 4. During the treatment period, PRL concentration was lower in the heifers and cows exposed to a short-day photoperiod than in those exposed to a long-day photoperiod $(P<0.001)$, was lower with 16L:8D-melatonin than with 16L:8D $(P<$ 

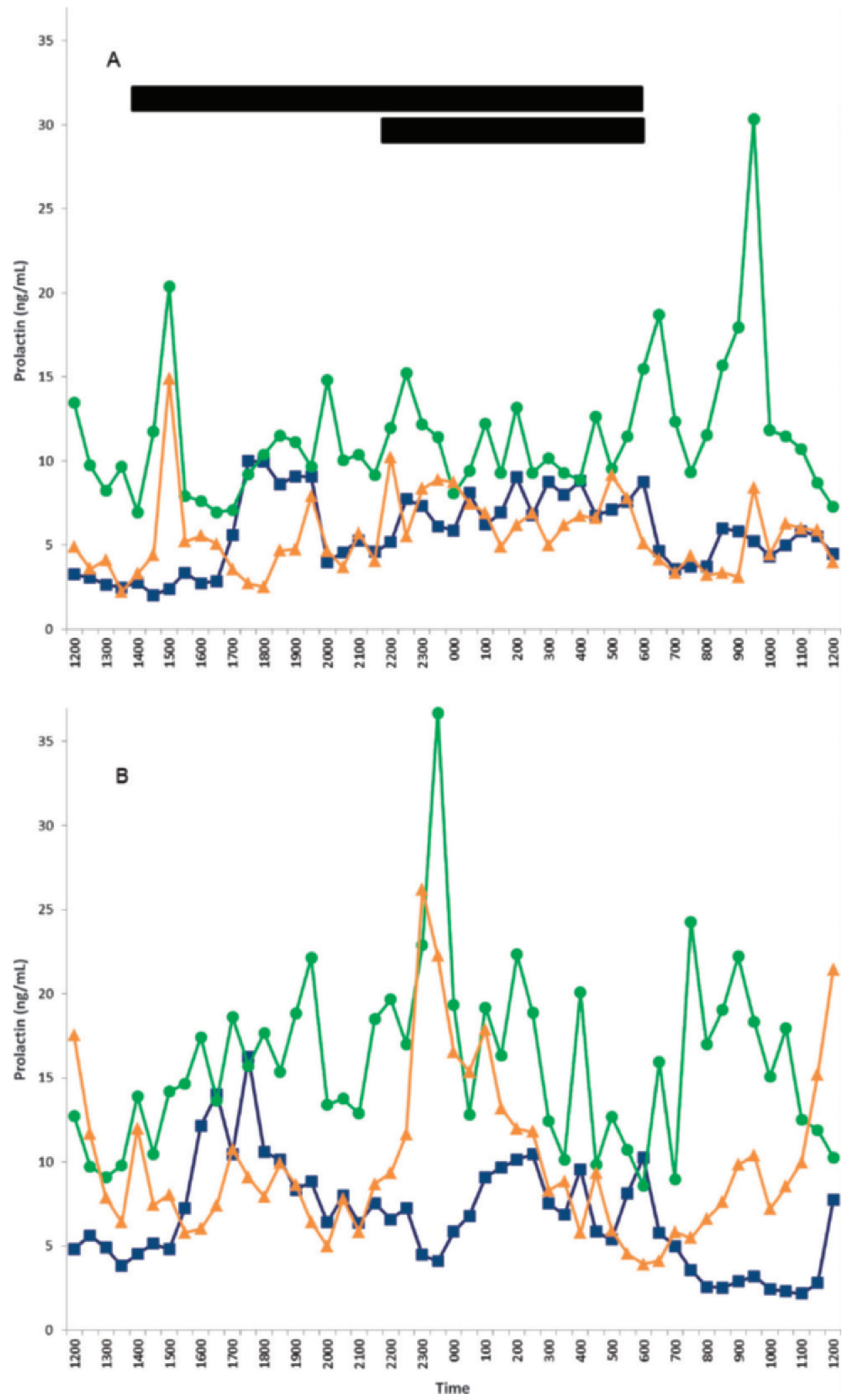

Figure 2. Blood prolactin concentration in heifers and cows exposed to $8 \mathrm{~h}$ of light and $16 \mathrm{~h}$ of dark (8L:16D; $\mathbf{0}), 16 \mathrm{~h}$ of light and $8 \mathrm{~h}$ of dark (16L:8D; $\bullet$ ), or 16L:8D with melatonin fed at $25 \mathrm{mg} / \mathrm{d}(\boldsymbol{\Delta})$ during the last 8 wk of gestation. Samples were collected over a 24-h period $8 \mathrm{wk}(\mathrm{A})$ and $2 \mathrm{wk}(\mathrm{B})$ before expected calving. Lights were off from 1400 to $0600 \mathrm{~h}$ (upper black bar) for 8L:16D and from $2200 \mathrm{ho} 0600 \mathrm{~h}$ (lower black bar) for 16L:8D. Data are presented as LSM; SE of LSM $\leq 4.1 \mathrm{ng} / \mathrm{mL}$. Color version available in the online PDF. 


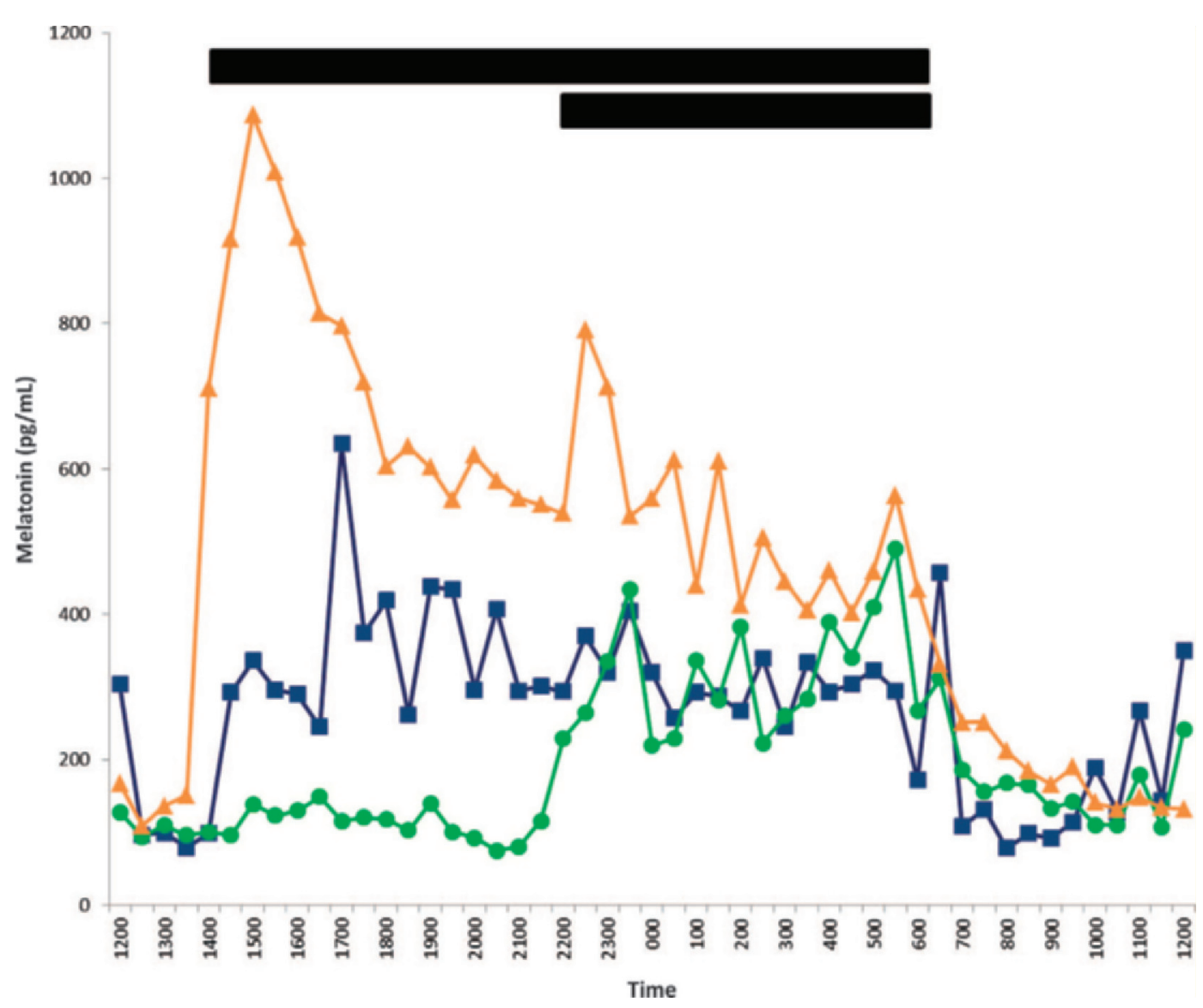

Figure 3. Blood melatonin concentration in heifers and cows exposed to $8 \mathrm{~h}$ of light and $16 \mathrm{~h}$ of dark $(8 \mathrm{~L}: 16 \mathrm{D} ; \mathbf{\square}), 16 \mathrm{~h}$ of light and $8 \mathrm{~h}$ of dark (16L:8D; $)$, or 16L:8D with melatonin fed at $25 \mathrm{mg} / \mathrm{d}(\boldsymbol{\Lambda})$ during the last 8 wk of gestation. Samples were collected over a $24-\mathrm{h}$ period 8 wk and 2 wk before expected calving. Lights were off from 1400 to $0600 \mathrm{~h}$ (upper black bar) for 8L:16D and from 2200 to $0600 \mathrm{~h}$ (lower black bar) for 16L:8D. Data from both sampling days were pooled and are presented as LSM; SE of LSM $\leq 85 \mathrm{pg} / \mathrm{mL}$. Color version available in the online PDF.

0.01 ), and tended to be lower with $8 \mathrm{~L}: 16 \mathrm{D}$ than with 16L:8D-melatonin, with averages of $3.5 \pm 0.8,9.9 \pm$ 0.8 , and $6.0 \pm 0.8 \mathrm{ng} / \mathrm{mL}$ for $8 \mathrm{~L}: 16 \mathrm{D}, 16 \mathrm{~L}: 8 \mathrm{D}$, and 16L:8D-melatonin, respectively. The concentration of PRL tended to be lower in cows $(5.7 \pm 0.7 \mathrm{ng} / \mathrm{mL})$ than in heifers $(7.3 \pm 0.6 \mathrm{ng} / \mathrm{mL} ; P=0.07)$. On the day of calving, PRL concentration was lower in the animals exposed to a short-day photoperiod than in those exposed to a long-day photoperiod $(P<0.05)$, with averages of $34.1 \pm 11.6,73.8 \pm 10.7$, and $58.8 \pm$ $10.8 \mathrm{ng} / \mathrm{mL}$ for 8L:16D, 16L:8D, and 16L:8D-melatonin, respectively. Because of interactions, postpartum PRL data were analyzed in 10-wk blocks and separately for heifers and for cows. In early lactation, PRL concentration was lower $(P<0.002)$ in the heifers exposed to the $16 \mathrm{~L}: 8 \mathrm{D}$ photoperiod than in those subjected to the 8L:16D photoperiod or fed melatonin (Figure 4A). Between wk 11 and 20 of lactation, PRL concentration tended to be lower $(P<0.08)$ in the heifers subjected to the $16 \mathrm{~L}: 8 \mathrm{D}$ photoperiod than in those subjected to the $8 \mathrm{~L}: 16 \mathrm{D}$ photoperiod. The treatments had no effect on the PRL concentration in heifers after wk 20 of lactation. The concentration of PRL during lactation in cows was not affected by the treatments (Figure 4B).

Plasma IGF-I concentration was determined using blood samples collected from calving to wk 6 of lactation. The concentration of IGF-I increased over time $(P<0.001)$ and was greater in heifers $(160.4 \pm 6.6 \mathrm{ng} /$ $\mathrm{mL})$ than in cows $(115.3 \pm 6.5 \mathrm{ng} / \mathrm{mL} ; P<0.001)$. The concentration of IGF-I tended to be greater in the animals fed melatonin than in those exposed to a shortday $(P=0.08)$ or long-day $(P=0.06)$ photoperiod, with averages of $128.1 \pm 8.4,132.2 \pm 7.7$, and $153.2 \pm$ $7.9 \mathrm{ng} / \mathrm{mL}$ for $8 \mathrm{~L}: 16 \mathrm{D}, 16 \mathrm{~L}: 8 \mathrm{D}$, and $16 \mathrm{~L}: 8 \mathrm{D}-m e l a t o n i n$, respectively.

\section{DISCUSSION}

In agreement with previous studies (Miller et al., 2000; Auchtung et al., 2005; Velasco et al., 2008), the 

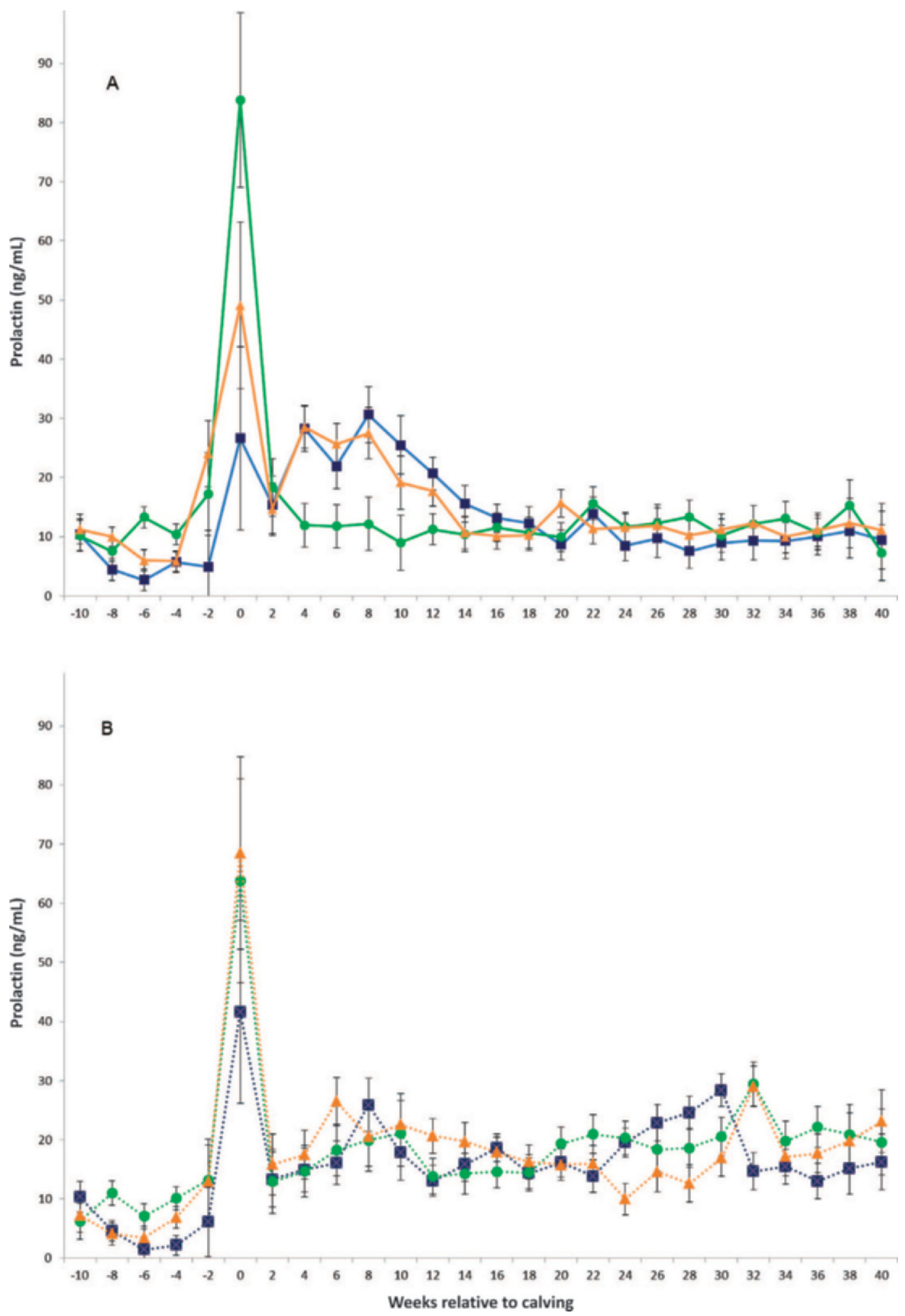

Figure 4. Blood prolactin concentration from $10 \mathrm{wk}$ before to $42 \mathrm{wk}$ after calving in heifers (solid lines; A) and cows (dotted lines; B) exposed to $8 \mathrm{~h}$ of light and $16 \mathrm{~h}$ of dark $(8 \mathrm{~L}: 16 \mathrm{D} ; \mathbf{\square}), 16 \mathrm{~h}$ of light and $8 \mathrm{~h}$ of dark $(16 \mathrm{~L}: 8 \mathrm{D} ; \bullet)$, or $16 \mathrm{~L}: 8 \mathrm{D}$ with melatonin fed at $25 \mathrm{mg} / \mathrm{d}(\mathbf{\Lambda})$ during the last 8 wk of gestation. Data are presented as LSM \pm SE of LSM. Color version available in the online PDF. 
present study found that milk production in multiparous cows in the first 20 wk of lactation was enhanced by about $10 \%$ by previous exposure to a short-day photoperiod. However, the effect decreased as lactation advanced, such that no stimulation was observed over the second $20 \mathrm{wk}$ of lactation. None of the previous studies reported results beyond wk 16 of lactation.

Feeding melatonin during the dry period did not affect milk production. In prepubertal heifers, a shortday photoperiod was previously shown to reduce PRL concentration and mammary growth (Petitclerc et al., 1985). Similarly, feeding melatonin in the middle of a long day $(16 \mathrm{~L}: 8 \mathrm{D})$ reduced PRL concentration and mammary parenchymal growth, supporting the hypothesis that melatonin can mimic a short-day photoperiod in cattle (Sanchez-Barcelo et al., 1991). In ewes, feeding or implanting melatonin overcame the restriction of seasonality of breeding (Stellflug et al., 1988). In lactating cows, melatonin implants decreased PRL concentration and lactation persistency in grazing lactating cows that received melatonin implants during summer (Auldist et al., 2007). Administration of melatonin implants to dairy cows at drying-off moderately suppressed prepartum PRL concentration but did not affect milk production (Garcia-Ispierto et al., 2013). In the present study, PRL concentration was reduced by melatonin feeding, but not as much as by a short-day photoperiod for cows. This finding may explain why melatonin feeding was not able to reproduce the effect of a short day on milk production.

Even though PRL concentration was affected by the photoperiod treatments, they did not affect postpartum milk production in heifers. Mammary growth, an important determinant of future milk production, is exponential during pregnancy, with most growth occurring in the last trimester (Swanson and Poffenbarger, 1979). Newbold et al. (1991) exposed Holstein heifers from 128 to $248 \mathrm{~d}$ of pregnancy to a long-day (16L:8D) or short-day (8L:16D) photoperiod. Despite a significant effect on serum PRL concentration, the photoperiod treatments had no effect on mammary gland development. This finding suggests that the mammary gland of primiparous heifers has a lower sensitivity to a photoperiodic signal. Nevertheless, feed efficiency in early lactation was improved by short-day photoperiod, which suggests that heifers responded to the photoperiodic signal. Moreover, in a previous study, heifers subjected to a short-day photoperiod in the last $8 \mathrm{wk}$ of gestation also had greater PRL concentration postpartum but, in contrast to the present study, produced 9\% more milk (Petitclerc et al., 1990).

Several mechanisms have been proposed to explain the effect of photoperiod during the dry period. Wall et al. (2005a) reported that cows exposed to a short- day photoperiod during the dry period underwent more extensive mammary remodeling and cell renewal, and those authors proposed that these changes translate into an increase in milk production in the following lactation. Instead, the present authors propose that the dry-period photoperiod is a signal in preparation for the subsequent lactation, because the previous photoperiod influences the response to the long-day photoperiod during lactation. Similarly, a long-day photoperiod was found to hasten puberty in heifers, but this effect was further enhanced if heifers had been exposed to a short-day photoperiod or treated with melatonin during the first 6 mo of life (Tortonese and Inskeep, 1992). In ewes, exposure to a short-day photoperiod during summer was shown to restore responsiveness to a longday photoperiod (Jackson et al., 1988). In nonpregnant heifers, we observed that a short-day photoperiod or a long-day photoperiod before 15 mo of age increased and decreased, respectively, the PRL response to subsequent photoperiod treatments (P. Lacasse and D. Petitclerc, unpublished data). The fact that the milk and PRL responses gradually decreased during lactation is more compatible with a galactopoietic response occurring during lactation than with a mammogenic response occurring during the dry period. Nevertheless, an experiment where photoperiod would also be manipulated before and after calving will be required to corroborate our hypothesis.

Several lines of evidence suggest that the reduction in the PRL concentration during the dry period is a determinant factor for the dry-period photoperiod effect. Shortening the dry period was shown to shorten the period of lower PRL concentration that precedes calving and leads to a decrease in milk production in the following lactation (Bernier-Dodier et al., 2011). Heat stress increases PRL concentration, and cooling during the dry period is followed by enhanced milk production (Tao and Dahl, 2013). Accordingly, infusion of recombinant PRL into cows exposed to a short-day photoperiod during the dry period reduced the milk response (Crawford et al., 2005). A series of studies (Ollier et al., 2012, 2013) on drying-off management found that PRL secretion was inhibited during the drying-off period. Even though those experiments were not designed to determine the effect of these treatments on milk production in the following lactation, an increase in production was observed in the animals that received the inhibitor [S. Ollier (Dairy and Swine Research and Development Centre, Sherbrooke, QC, Canada), X. Zhao (McGill University, Montreal, QC, Canada), and P. Lacasse, unpublished data]. Although experiments carried out in the 1970s and 1980s suggest that PRL is not galactopoietic in cattle [see Lacasse et al. (2012) for a review], recent studies performed 
during an established lactation have shown that PRL secretion inhibition decreases milk production (Lacasse et al., 2011) and stimulation of PRL secretion increases it [P. Lacasse, S. Ollier (Dairy and Swine Research and Development Centre, Sherbrooke, QC, Canada), and X. Zhao (McGill University, Montreal, QC, Canada), unpublished data], demonstrating the galactopoietic potential of this hormone. In the present experiment, postpartum PRL concentration was enhanced by a previous short-day photoperiod in heifers but not in cows, a finding that does not support changes in postpartum PRL secretion as the mechanism of action of the dryperiod photoperiod. Nevertheless, a short-day photoperiod during the dry period has been associated with greater expression of PRL receptors (Auchtung et al., 2005) and lower expression of suppressors of cytokine signaling (Wall et al., 2005b) in the mammary gland, suggesting increased responsiveness and sensitivity to PRL.

It has also been proposed that IGF-I mediates the mammogenic and galactopoietic effects of photoperiod (Dahl et al., 1997; Spicer et al., 2007). Dairy goats exposed to a short-day photoperiod during the dry period had lower IGF-I concentration during the dry period but not during the following lactation despite increased milk production (Mabjeesh et al., 2007). Similarly, the present authors did not observe greater IGF-I concentration in cows exposed to a short-day photoperiod and, therefore, do not support the idea that IGF-I is involved in the photoperiod effect during the dry period.

\section{CONCLUSIONS}

The results of this experiment confirm that a shortday photoperiod during the dry period enhances milk production in multiparous cows in the following lactation. However, this effect is gradually lost and cannot be mimicked by feeding melatonin. Photoperiod treatments during the last 2 mo of gestation do not appear to affect the following lactation in primiparous heifers, although feed efficiency was improved by precalving exposure to short-day photoperiod; however, this effect is different from those found in previous studies in heifers and will need to be confirmed by additional experimental data.

\section{ACKNOWLEDGMENTS}

The authors thank the following people from Agriculture and Agri-Food Canada (Sherbrooke, QC, Canada): Jasmin Brochu and Gilles Gilbert for providing technical assistance, Steve Méthot for helping with statistical analyses, and the dairy barn staff for taking care of the animals. The authors are grateful to Mary
Varcoe from the Translation Bureau, Public Works and Government Services Canada (Gatineau, QC, Canada), for her careful editing of this manuscript. The authors also thank the National Hormone and Peptide Program (Harbor-UCLA Medical Center, Torrance, CA) and A. F. Parlow (Harbor-UCLA Medical Center) for providing the bovine prolactin and antibodies.

\section{REFERENCES}

Abribat, T., H. Lapierre, P. Dubreuil, G. Pelletier, P. Gaudreau, P. Brazeau, and D. Petitclerc. 1990. Insulin-like growth factor-I concentration in Holstein female cattle: Variations with age, stage of lactation and growth hormone-releasing factor administration. Domest. Anim. Endocrinol. 7:93-102.

Auchtung, T. L., A. G. Rius, P. E. Kendall, T. B. McFadden, and G. E. Dahl. 2005. Effects of photoperiod during the dry period on prolactin, prolactin receptor, and milk production of dairy cows. J. Dairy Sci. 88:121-127.

Auldist, M. J., S. A. Turner, C. D. McMahon, and C. G. Prosser. 2007. Effects of melatonin on the yield and composition of milk from grazing dairy cows in New Zealand. J. Dairy Res. 74:52-57.

Bernier-Dodier, P., C. L. Girard, B. G. Talbot, and P. Lacasse. 2011. Effect of dry period management on mammary gland function and its endocrine regulation in dairy cows. J. Dairy Sci. 94:4922-4936.

Burchard, J. F., D. H. Nguyen, H. G. Monardes, and D. Petitclerc. 2004. Lack of effect of $10 \mathrm{kV} / \mathrm{m} 60 \mathrm{~Hz}$ electric field exposure on pregnant dairy heifer hormones. Bioelectromagnetics 25:308-312.

Crawford, H. M., J. L. Dauderman, D. E. Morin, T. B. McFadden, and G. E. Dahl. 2005. Evidence of a role of prolactin in mediating photoperiodic effects during the dry period. J. Dairy Sci. 88(Suppl. 1):363. (Abstr.)

Dahl, G. E., T. H. Elsasser, A. V. Capuco, R. A. Erdman, and R. R. Peters. 1997. Effects of a long daily photoperiod on milk yield and circulating concentrations of insulin-like growth factor-1. J. Dairy Sci. 80:2784-2789.

Dahl, G. E., and D. Petitclerc. 2003. Management of photoperiod in the dairy herd for improved production and health. J. Anim. Sci. 81(Suppl. 3):11-17.

Garcia-Ispierto, I., A. Abdelfatah, and F. López-Gatius. 2013. Melatonin treatment at dry-off improves reproductive performance postpartum in high-producing dairy cows under heat stress conditions. Reprod. Domest. Anim. 48:577-583.

Jackson, G. L., M. Gibson, and D. Kuehl. 1988. Photoperiodic disruption of photorefractoriness in the ewe. Biol. Reprod. 38:127-134.

Lacasse, P., V. Lollivier, R. M. Bruckmaier, Y. R. Boisclair, G. F. Wagner, and M. Boutinaud. 2011. Effect of the prolactin-release inhibitor quinagolide on lactating dairy cows. J. Dairy Sci. 94:1302-1309.

Lacasse, P., V. Lollivier, F. Dessauge, R. M. Bruckmaier, S. Ollier, and M. Boutinaud. 2012. New developments on the galactopoietic role of prolactin in dairy ruminants. Domest. Anim. Endocrinol. 43:154-160.

Lapierre, H., D. Petitclerc, G. Pelletier, L. Delorme, P. Dubreuil, J. Morisset, P. Gaudreau, Y. Couture, and P. Brazeau. 1990. Effect of human growth hormone-releasing factor and(or) thyrotropinreleasing factor on hormone concentrations in dairy calves. J. Anim. Sci. 68:2436-2449.

Mabjeesh, S. J., O. Gal-Garber, and A. Shamay. 2007. Effect of photoperiod in the third trimester of gestation on milk production and circulating hormones in dairy goats. J. Dairy Sci. 90:699-705.

Miller, A. R. E., R. A. Erdman, L. W. Douglass, and G. E. Dahl. 2000. Effects of photoperiodic manipulation during the dry period of dairy cows. J. Dairy Sci. 83:962-967.

Newbold, J. A., L. T. Chapin, S. A. Zinn, and H. A. Tucker. 1991. Effects of photoperiod on mammary development and concentration of hormones in serum of pregnant dairy heifers. J. Dairy Sci. 74:100-108. 
Ollier, S., X. Zhao, and P. Lacasse. 2012. Effects of feed restriction and prolactin-release inhibition at drying-off on milk production, metabolism and mammary gland involution. J. Dairy Sci. 95(ESuppl. 1):301. (Abstr.)

Ollier, S., X. Zhao, and P. Lacasse. 2013. Effect of prolactin-release inhibition on milk production and mammary gland involution at drying-off in cows. J. Dairy Sci. 96:335-343.

Petitclerc, D., R. D. Kineman, S. A. Zinn, and H. A. Tucker. 1985. Mammary growth response of Holstein heifers to photoperiod. J. Dairy Sci. 68:86-90.

Petitclerc, D., C. M. Vinet, and P. Lacasse. 1990. Peripartum effects of photoperiod and lactose on primiparous Holstein heifers. Pages 86-87 in Proc. 41st Annu. Mtg. EAAP. European Federation of Animal Science (EAAP), Rome, Italy

Sanchez-Barcelo, E. J., M. D. Mediavilla, S. A. Zinn, B. A. Buchanan, L. T. Chapin, and H. A. Tucker. 1991. Melatonin suppression of mammary growth in heifers. Biol. Reprod. 44:875-879.

Spicer, L. J., B. A. Buchanan, L. T. Chapin, and H. A. Tucker. 2007. Effect of exposure to various durations of light on serum insulinlike growth factor-I in prepubertal Holstein heifers. Am. J. Anim. Vet. Sci. 2:42-45.

Stanisiewski, E. P., L. T. Chapin, N. K. Ames, S. A. Zinn, and H. A. Tucker. 1988. Melatonin and prolactin concentrations in blood of cattle exposed to 8, 16 or 24 hours of daily light. J. Anim. Sci. $66: 727-734$.

Stellflug, J. N., J. A. Fitzgerald, C. F. Parker, and D. Bolt. 1988. Influence of concentration, duration and route of administration of melatonin on reproductive performance of spring-mated Polypay and Polypay-cross ewes. J. Anim. Sci. 66:1855-1863.
Swanson, E. W., and J. I. Poffenbarger. 1979. Mammary gland development of dairy heifers during their first gestation. J. Dairy Sci. 62:702-714.

Tao, S., and G. E. Dahl. 2013. Invited review: Heat stress effects during late gestation on dry cows and their calves. J. Dairy Sci. 96:4079-4093.

Tortonese, D. J., and E. K. Inskeep. 1992. Effects of melatonin treatment on the attainment of puberty in heifers. J. Anim. Sci. $70: 2822-2827$.

Velasco, J. M., E. D. Reid, K. K. Fried, T. F. Gressley, R. L. Wallace, and G. E. Dahl. 2008. Short-day photoperiod increases milk yield in cows with a reduced dry period length. J. Dairy Sci. 91:3467-3473

Wall, E. H., T. L. Auchtung, G. E. Dahl, S. E. Ellis, and T. B. McFadden. 2005a. Exposure to short day photoperiod during the dry period enhances mammary growth in dairy cows. J. Dairy Sci. 88:1994-2003.

Wall, E. H., T. L. Auchtung-Montgomery, G. E. Dahl, and T. B. McFadden. 2005b. Short communication: Short-day photoperiod during the dry period decreases expression of suppressors of cytokine signaling in mammary gland of dairy cows. J. Dairy Sci. $88: 3145-3148$

Zinn, S. A., L. T. Chapin, W. J. Enright, A. L. Schroeder, E. R. Stanisiewski, and H. A. Tucker. 1988. Growth, carcass composition and plasma melatonin in postpubertal beef heifers fed melatonin. J. Anim. Sci. 66:21-27. 